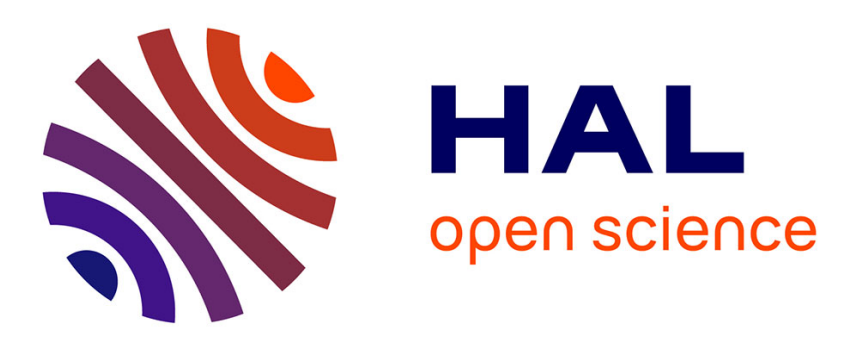

\title{
Assignment of the solute carrier family 27 member 1 (SLC27A1)gene to bovine chromosome 7
}

L. Ordovas, R. Roy, P. Zaragoza, Hélène Hayes, Andre A. Eggen, C. Rodellar

\section{To cite this version:}

L. Ordovas, R. Roy, P. Zaragoza, Hélène Hayes, Andre A. Eggen, et al.. Assignment of the solute carrier family 27 member 1 (SLC27A1)gene to bovine chromosome 7. Animal Genetics, 2005, 36, pp.352-353. hal-02676420

\section{HAL Id: hal-02676420 \\ https://hal.inrae.fr/hal-02676420}

Submitted on 31 May 2020

HAL is a multi-disciplinary open access archive for the deposit and dissemination of scientific research documents, whether they are published or not. The documents may come from teaching and research institutions in France or abroad, or from public or private research centers.
L'archive ouverte pluridisciplinaire HAL, est destinée au dépôt et à la diffusion de documents scientifiques de niveau recherche, publiés ou non, émanant des établissements d'enseignement et de recherche français ou étrangers, des laboratoires publics ou privés. 
doi:10.1111/j.1365-2052.2005.01321.x

\section{Assignment of the solute carrier family 27 member 1 (SLC27A1) gene to bovine chromosome 7}

\section{Ordovás*, R. Roy*, P. Zaragoza*, H. Hayes ${ }^{\dagger}$, A. Eggen $^{\dagger}$ and C. Rodellar*}

* Laboratorio de Genética Bioquímica, Facultad de Veterinaria, Universidad de Zaragoza, Zaragoza 50013, Spain. ' Laboratoire de Génétique Biochimique et de Cytogénétique, INRA-CRJ, Jouy-enJosas 78350, France

Accepted for publication 28 February 2005

Source/description: Long chain fatty acids (LCFAs) are an important source of energy for most organisms and are also involved in different cellular processes such as membrane synthesis, intracellular signalling, protein modification and transcriptional regulation. SLC27A1 is a membrane protein that facilitates LCFAs transport across the plasma membrane. ${ }^{1}$ It may play a key role in regulating available LCFAs substrates from exogenous sources in tissues undergoing high levels of $\beta$-oxidation or triglycerides synthesis. SLC27A1 protein is present in several tissues. ${ }^{2}$ Skeletal and heart muscle and adipose tissue are the tissues with the highest levels of SLC27A1 mRNA in man. ${ }^{2}$ SLC27A1 has been cloned in man, ${ }^{2}$ rat $^{1}$ and mouse. ${ }^{3}$

Primer sequences: In order to obtain a bovine SLC27A1 DNA fragment, PCR was performed using the following set of primers:

Forward: 5'-CTG CTC AAC GTG AAC CTG C-3'

Reverse: 5'-GGT CCC CGA CGT GTA GAT G-3'

Primers were designed from the human SLC27A1 mRNA sequence (GenBank no. NM_198580) and amplified a 505 bp specific-bovine fragment (GenBank no. AY738458).

PCR conditions: The PCR reaction was performed in $25 \mu \mathrm{l}$ using $50 \mathrm{ng}$ bovine genomic DNA, standard PCR buffer, $1.5 \mathrm{~mm}$ $\mathrm{MgCl}_{2}, 100 \mu \mathrm{M}$ each dNTP, $240 \mathrm{~nm}$ each primer and $1.25 \mathrm{U}$ Taq DNA polymerase (Invitrogen, Barcelona, Spain). The PCR profile included an initial denaturation step of $95^{\circ} \mathrm{C}$ for $5 \mathrm{~min}$ and a final extension step of $72{ }^{\circ} \mathrm{C}$ for $5 \mathrm{~min}$. Cycling conditions were $94{ }^{\circ} \mathrm{C}$ for $30 \mathrm{~s}, 58{ }^{\circ} \mathrm{C}$ for $30 \mathrm{~s}$ and $72{ }^{\circ} \mathrm{C}$ for $30 \mathrm{~s}$ for 35 cycles. The PCR fragment was sequenced and showed a high level of sequence identity (91 and 80\%) with coding regions (exons 2 and 3 respectively) of the orthologous human gene.

Screening of a bovine BAC library: A bovine bacterial artificial chromosome (BAC) library ${ }^{4}$ was screened by PCR and a BAC clone containing the bovine SLC27A1 gene was identified. The positive BAC clone (927A3) was partially sequenced and the presence of SLC27A1 gene was confirmed.

Fluorescent in situ hybridization: Fluorescent in situ hybridization was performed on bovine, ovine and caprine chromosome spreads prepared from fibroblast cell cultures from normal embryos. $^{5}$ The BAC clone, 927A3, containing the bovine SLC27A1 gene was used as a probe. The R-banded chromosome spreads were obtained by synchronizing cell cultures with an excess of thymidine and by treating them with 5-bromode- oxyuridine during the second half of $S$ phase. The BAC DNA extracts were prepared according to standard protocols and the probes were nick-translated in the presence of biotine-14-dATP with the BioNick labelling system (Invitrogen) and prepared for hybridization. ${ }^{6}$ Chromosome and band numbering followed the ISCNDB 2000 bovine nomenclature. $^{7}$

Chromosomal location: Clear and consistent hybridization signals were obtained in the three species (Fig. 1). The SLC27A1
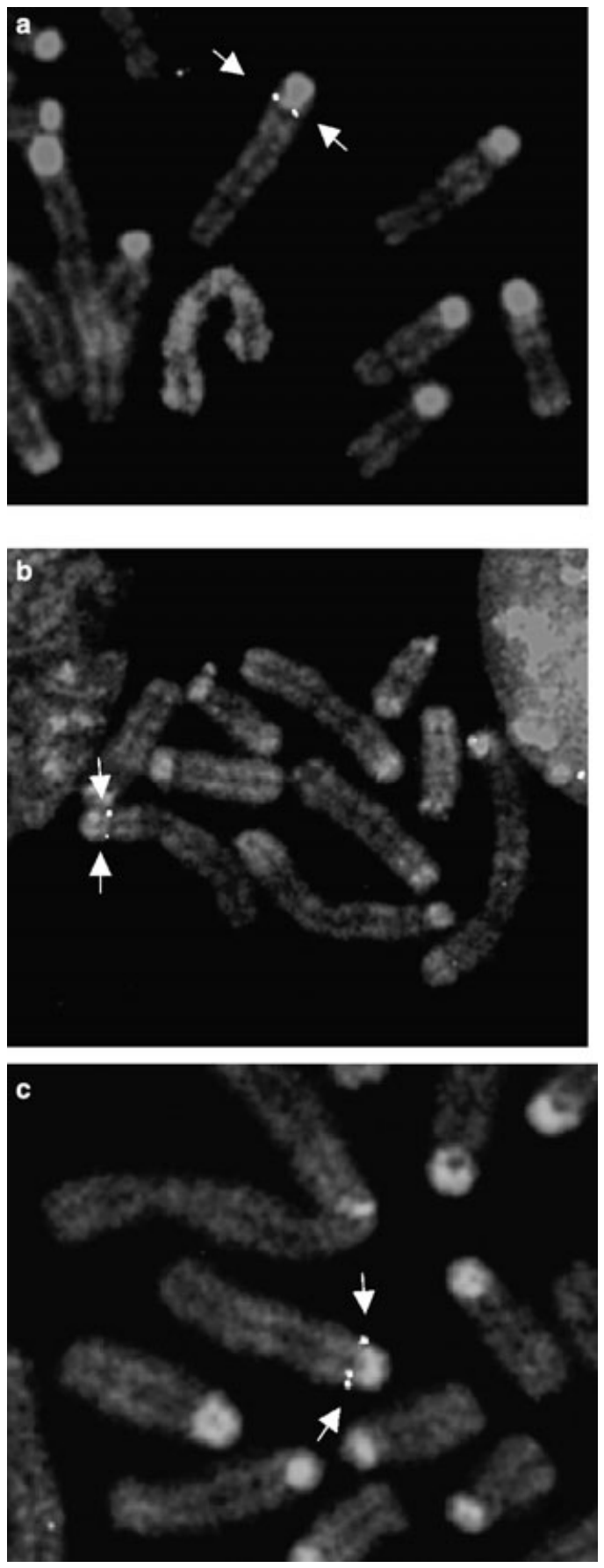

Figure 1 Chromosome mapping of SLC27A1 by fluorescent in situ hybridization. A specific signal is observed on chromosomes 7q11-q12 in cattle (a), 7q11-q12 in goat (b) and 5q11-q12 in sheep (c). 
gene is located on the homologous bovine and caprine chromosomes 7q11-q12 and ovine chromosome 5q11-q12, which is in agreement with comparative mapping results in man (HSA19p13.12), mouse (MMU8B3.3) and rat (RNO16p14), as these segments are conserved with bovine chromosome $7 .^{8}$

\section{References}

1 Schaffer J. E. et al. (1994) Cell 79, 427-36.

2 Martin G. et al. (2000) Genomics 66, 296-304.

3 Hui T. Y. et al. (1998) J Biol Chem 42, 27420-9.

4 Eggen A. et al. (2001) Genet Sel Evol 33, 543-8.

5 Hayes H. et al. (1991) Cytogenet Cell Genet 57, 51-55.

6 Hayes H. et al. (2002) Cytogenet Genome Res 98, 199-205.

7 Cribiu E. P. et al. (2001) Cytogenet Cell Genet 92, 283-99.

8 Hayes H. et al. (2003) Cytogenet Genome Res 102, 16-24.

Correspondence: L. Ordovás (lordovas@unizar.es)

doi:10.1111/j.1365-2052.2005.01304.x

\section{Localization of $X b a$ repetitive elements to channel catfish (/ctalurus punctatus) centromeres via fluorescence in situ hybridization.}

\section{S. M. A. Quiniou, W. R. Wolters and G. C. Waldbieser}

USDA, ARS, Catfish Genetics Research Unit, 141 Experiment Station Road, Stoneville, MS 38776, USA. Present address: W. R. Wolters, USDA, ARS, National Cold Water Marine Aquaculture Center, 5717 Corbett Hall, Orono, ME 04469, USA

Accepted for publication 31 March 2005

Source/description: To date, four classes of repetitive DNA have been identified in the channel catfish (Ictalurus punctatus) genome. The most abundant repeat class is approximately $325 \mathrm{bp}$ A/T-rich Xba element with approximately 150000 copies in the catfish genome, ${ }^{1}$ but these elements have not been localized in catfish. Approximately 32000 copies of Tipnon a $535 \mathrm{bp}$ Tc1-like transposable element, are dispersed throughout the genome. ${ }^{2}$ The catfish genome also contains approximately 9000 copies of the 57 bp Mermaid and approximately 1200 copies of the $64 \mathrm{bp}$ Merman elements, which are short interspersed repetitive elements found in many bony fish. ${ }^{3}$ An all-human telomere probe (TTAGGG) ${ }_{n}$ have been previously localized to the telomeres of catfish metaphase chromosomes by fluorescence in situ hybridization (FISH) ${ }^{4}$ Because the Xba elements are the largest repeat class characterized to date in catfish (5-6\% of the genome), this study was designed to determine the genomic distribution of these repeats using FISH.

Primer development: Primers were designed to highly conserved regions on each end of seven Xba elements (GenBank accession nos AF112193-AF112199) ${ }^{3}$. The forward primer (5'-CTAGAAAGTAAGTATTGAACAAAAGTAC-3') perfectly matched to elements $X b a-1$ to -5 , and contained three mismatches to elements $X b a-6$ and -7 at positions 14,17 and 19. The reverse primer (5'-GTCACTTTTTTCACCTTATCATAC-3') was perfectly

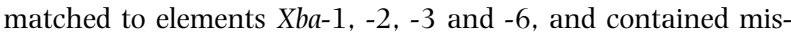
matches at nucleotide positions 11 and 18 to $X b a-4$ and 5, and a mismatch at position 3 to $X b a-7$. Because of the sequence similarity between the seven Xba element sequences (>95\%), we expected the fragment amplified with these primers to hybridize to all elements.

PCR conditions: The hybridization probe was produced by PCR amplification from genomic DNA isolated from the T-cell line G14D. ${ }^{5}$ The 50- $\mu$ PCR reaction contained $20 \mathrm{~mm}$ Tris- $\mathrm{HCl}(\mathrm{pH}$ 8.4), $50 \mathrm{~mm} \mathrm{KCl,} 1.5 \mathrm{~mm} \mathrm{MgCl}_{2}, 800 \mathrm{~nm}$ of each primer, $200 \mu \mathrm{m}$ of each deoxynucleotides, $2 \%$ glycerol, $100 \mu \mathrm{m}$ digoxigenin-11-dUTP, $1 \mu \mathrm{l}$ Accuprime Taq polymerase and $30 \mathrm{ng}$ genomic DNA. The PCR cycling protocol was $95{ }^{\circ} \mathrm{C}$ for $5 \mathrm{~min}$, 45 cycles of $95{ }^{\circ} \mathrm{C}$ for $15 \mathrm{~s}, 50{ }^{\circ} \mathrm{C}$ for $15 \mathrm{~s}, 72{ }^{\circ} \mathrm{C}$ for $30 \mathrm{~s}$ and a final extension at $72{ }^{\circ} \mathrm{C}$ for $5 \mathrm{~min}$. The PCR fragments were purified on micro Bio-spin 30 chromatography columns (Bio-Rad, Hercules, CA, USA) by centrifugation at $1000 \mathrm{~g}$.

Chromosomal localization by FISH: The Xba elements were hybridized to channel catfish metaphase chromosomes using $25 \mathrm{ng}$ of digoxigenin-labelled Xba probe in 30- $\mu$ l hybridization buffer. Hybridization and one-step detection with FITC-labelled anti-digoxigenin was performed as previously described. ${ }^{6}$ Ten metaphase chromosome spreads were analysed in each of four replicate experiments. Signal was detected at the centromere of every chromosome pair with variability in signal intensity between chromosome pairs (Fig. 1).

Comments: A recent BLAST search of catfish Xba elements against mammalian, chicken, zebrafish, and fugu genomic sequences revealed no significant matches. However, the Xba element sequences identified within this study will help researchers identify genomic clones and contigs containing centromeric DNA. This information will be useful in the assembly of catfish genetic maps, the integration of genetic and

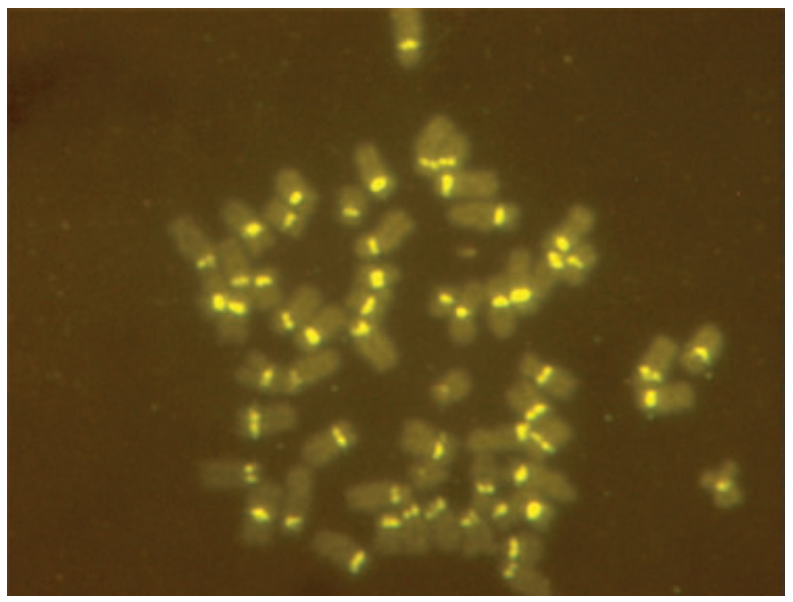

Figure 1 Fluorescence in situ hybridization of A/T-rich Xba repetitive elements labelled with digoxigenin and detected with FITC-labelled anti-digoxigenin on channel catfish metaphase chromosomes $(2 n=58)$. 